\title{
lowa Variant of Familial Alzheimer's Disease
}

\section{Accumulation of Posttranslationally Modified A $B D 23 N$ in Parenchymal and Cerebrovascular Amyloid Deposits}

\author{
Yasushi Tomidokoro, ${ }^{*}$ Agueda Rostagno, ${ }^{*}$ \\ Thomas A. Neubert, ${ }^{\dagger \ddagger}$ Yun Lu, ${ }^{\ddagger}$ \\ G. William Rebeck, ${ }^{\S}$ Blas Frangione, ${ }^{* \mathrm{CI}}$ \\ Steven M. Greenberg," and Jorge Ghiso* ${ }^{*}$ \\ From the Departments of Pathology, Pharmacology, ${ }^{\dagger}$ and \\ Psychiatry, "The Kimmel Center for Biology and Medicine at the \\ Skirball Institute, ${ }^{\ddagger}$ New York University School of Medicine, New \\ York, New York; the Department of Neuroscience, Georgetown \\ University, Washington, DC; and the Department of Neurology, " \\ Massachusetts General Hospital, Boston, Massachusetts
}

Mutations within the amyloid- $\beta$ (A $\beta)$ sequence, especially those clustered at residues 21-23, which are linked to early onset familial Alzheimer's disease (AD), are primarily associated with cerebral amyloid angiopathy (CAA). The basis for this predominant vascular amyloid burden and the differential clinical phenotypes of cerebral hemorrhage/stroke in some patients and dementia in others remain unknown. The $A \beta D 23 N$ Iowa mutation is associated with progressive AD-like dementia, often without clinically manifested intracerebral hemorrhage. Neuropathologically, the disease is characterized by predominant preamyloid deposits, severe CAA, and abundant neurofibrillary tangles in the presence of remarkably few mature plaques. Biochemical analyses using a combination of immunoprecipitation, mass spectrometry, amino acid sequence, and Western blot analysis performed after sequential tissue extractions to separately isolate soluble components, preamyloid, and fibrillar amyloid species indicated that the Iowa deposits are complex mixtures of mutated and nonmutated $\mathbf{A} \boldsymbol{\beta}$ molecules. These molecules exhibited various degrees of solubility, were highly heterogeneous at both the $\mathrm{N}$ - and $\mathrm{C}$-termini, and showed partial aspartate isomerization at positions 1,7 , and 23 . This collection of $A \beta$ species-the Iowa brain $A \beta$ peptidome-contained clear imprints of amyloid clearance mechanisms yet highlighted the unique neuropathological features shared by a non-A $\beta$ cerebral amyloidosis, familial Danish dementia, in which neurofibrillary tangles coexist with extensive pre-amyloid deposition in the virtual absence of fibrillar lesions. These data therefore challenge the importance of neuritic plaques as the sole contributors for the development of dementia. (AmJ Pathol 2010, 176:1841-1854; DOI: 10.2353/ajpath.2010.090636)

Amyloid $\beta(A \beta)$ is the major constituent of the fibrils deposited in senile plaques and cerebral blood vessels of patients with Alzheimer's disease (AD) and Down's syndrome. It is an internal processing product of a larger type-I transmembrane precursor molecule APP, which is encoded by a single multiexonic gene located on chromosome 21. ${ }^{1}$ Several mutations in the APP gene are associated with early onset familial AD (FAD) [reviewed in Refs. 2 and 3 and AD Mutation Database (www.molgen. ua.ac.be/ADMutations/)]. Many of these mutations, located either $5^{\prime}$ or $3^{\prime}$ of the nucleotide sequence coding for the $A \beta$ peptide, result in an overproduction of $A \beta$, particularly $A \beta 42$, and are clinically associated with $A D$ phenotype. In contrast, mutations located within the $A \beta$ sequence (Table $1^{4-16}$ ) are typically linked to early onset FAD and primarily associated with cerebral amyloid angiopathy (CAA), although they manifest with either cerebral hemorrhage or dementia. The bulk of the CAA-associated mutations are located in a short stretch-positions

Supported by National Institutes of Health grants AG10491, AG005891, AG30539, NS051715, and P30 NS050276 and Shared Instrumentation grant RR14662, the Alzheimer's Association, and the American Heart Association.

Accepted for publication December 4, 2009.

Supplemental material for this article can be found on http://ajp. amjpathol.org

Current address of Y.T.: Department of Neurology, Tsukuba University, Tsukuba, Japan

Address reprint requests to Jorge Ghiso, Ph.D., Departments of Pathology and Psychiatry, New York University School of Medicine, 550 First Avenue (TH-432), New York, NY 10016. E-mail: jorge.ghiso@nyumc.org. 
Table 1. APP Mutations Located within the A $\beta$ Sequence

\begin{tabular}{|c|c|c|c|c|c|c|c|c|c|c|c|}
\hline \multirow[b]{3}{*}{ Kindred } & \multirow{3}{*}{$\begin{array}{l}\text { Nucleotide } \\
\text { change }\end{array}$} & \multirow{3}{*}{ Zygosity } & \multirow{3}{*}{$\begin{array}{c}\text { APP } \\
\text { codon }\end{array}$} & \multirow{3}{*}{$\begin{array}{c}\mathrm{A} \beta \\
\text { mutation }\end{array}$} & \multirow{3}{*}{$\begin{array}{l}\text { Onset } \\
\text { (yrs) }\end{array}$} & \multicolumn{2}{|c|}{ Clinical phenotype } & \multirow{2}{*}{\multicolumn{3}{|c|}{ Neuropathology }} & \multirow[b]{3}{*}{ References } \\
\hline & & & & & & \multirow{2}{*}{$\begin{array}{l}\text { Cognitive } \\
\text { impairment }\end{array}$} & \multirow{2}{*}{$\begin{array}{c}\text { Stroke/ } \\
\text { hemorrhage }\end{array}$} & & & & \\
\hline & & & & & & & & Plaques & NFTs & CAA & \\
\hline Italian & $\mathrm{C}>\mathrm{T}$ & Homo & 673 & $\mathrm{~A} \beta \mathrm{A} 2 \mathrm{~V}$ & 36 & Yes & No & - & - & - & 4 \\
\hline British & $A>G$ & Hetero & 677 & $\mathrm{~A} \beta \mathrm{H} 6 \mathrm{R}$ & 55 & Yes & No & - & - & - & 5 \\
\hline Tottori & $G>A$ & Hetero & 678 & $\mathrm{~A} \beta \mathrm{D} 7 \mathrm{~N}$ & 60 & Yes & No & - & - & - & 6 \\
\hline Flemish & $C>G$ & Hetero & 692 & $\mathrm{~A} \beta \mathrm{A} 21 \mathrm{G}$ & $35-60$ & Yes & Yes & Perivascular & Yes & Massive & 7 \\
\hline Dutch & $G>C$ & Hetero & 693 & $\mathrm{~A} \beta \mathrm{E} 22 \mathrm{Q}$ & $30-40$ & Yes & Yes & Diffuse & Rare & Massive & 8 \\
\hline Italian & $G>A$ & Hetero & 693 & $\mathrm{~A} \beta \mathrm{E} 22 \mathrm{~K}$ & $50-60$ & Mild & Yes & Diffuse & No & Massive & 9 \\
\hline Arctic & $A>G$ & Hetero & 693 & $\mathrm{~A} \beta \mathrm{E} 22 \mathrm{G}$ & $55-60$ & Yes & No & Compact & Yes & Scarce & 10,11 \\
\hline Japanese & $\operatorname{del} A G A$ & Hetero & 693 & A $\beta$ E22 $\Delta$ & $40-59$ & Yes & No & - & - & - & 12 \\
\hline lowa & $G>A$ & Hetero & 694 & $\mathrm{~A} \beta \mathrm{D} 23 \mathrm{~N}$ & $50-60$ & Yes & Rare & Diffuse & Yes & Massive & 13 \\
\hline Piedmont & $C>G$ & Hetero & 705 & $A \beta\llcorner 34 V$ & $50-70$ & Yes & Yes & No & No & Massive & 14 \\
\hline Italian/Spanish & $G>A$ & Hetero & 713 & $\mathrm{~A} \beta \mathrm{A} 42 \mathrm{~T}$ & $58-68$ & Yes & Yes & Compact & Yes & Massive & 15,16 \\
\hline
\end{tabular}

-, unknown.

\section{1-23 - of $A \beta$ although more recently others have been} reported.

The first described $A \beta$ mutation was found in a Dutch kindred, in which GIn replaced Glu at position 22 $(\mathrm{A} \beta \mathrm{E} 22 \mathrm{Q})$ as a result of a single nucleotide transversion ( $G$ for $C$ ) at codon $693 .^{8}$ Carriers of the mutation develop recurrent episodes of cerebral hemorrhages that correlated with massive amyloid deposition in the walls of leptomeningeal and cortical arteries and arterioles as well as in vessels in the brainstem and cerebellum. ${ }^{17}$ This phenotype was recapitulated, albeit at old age, in transgenic mice carrying the mutation. ${ }^{18}$ In addition to the vascular involvement, parenchymal amyloid deposits resembling the diffuse preamyloid lesions seen in $A D$ are also observed in Dutch familial cases, whereas densecore plaques and neurofibrillary tangles are rare or even completely absent. ${ }^{8}$ Cognitive deterioration generally manifests after the first stroke but in some cases it is the first symptom of the disease and may develop even before the appearance of focal lesions on brain imaging. ${ }^{2,19} \mathrm{~A}$ similar neuropathological phenotype with comparable clinical presentation to the Dutch form has been more recently reported in a Piedmont kindred in which a $G$ for $C$ transversion at codon 705 results in Leu for Val substitution at position 34 of $A \beta(A \beta L 34 V) .{ }^{14}$ Neuropathological examination of the few available cases showed severe CAA with compromise of small and medium-size arteries as well as capillaries in all lobes of the brain, particularly the occipital and cerebellar regions. The vascular involvement includes vessel-within-vessel configurations, microhemorrhages, microaneurisms, microthrombi, and lymphocytic infiltration of the vessel walls whereas diffuse and dense-cored plaques as well as neurofibrillary pathology are notably absent. Cognitive impairment is infrequent as a presenting symptom but it is observed after various episodes of intracerebral hemorrhages. ${ }^{2}$

Two additional genetic variants were described at position 22 of $A \beta$ in kindreds from Italy and Sweden. The Italian variant presents extensive CAA with hemorrhagic episodes of variable frequency depending on the individual cases. It relates to a $G$ for $A$ point mutation at codon 693 which translates in the replacement of Glu for Lys at position 22 of $A \beta(A \beta E 22 K) .{ }^{9}$ This variant is clini- cally characterized by a 10-20 year progression of recurrent strokes and mild cognitive decline. The neuropathological findings resemble those in the Dutch kindred with extensive $A \beta$ deposits in the walls of leptomeningeal and cortical vessels whereas parenchymal compromise is limited to diffuse deposits with absence of mature plaques and neurofibrillary tangles. In contrast, patients from the Swedish kindred develop typical $A D$ pathology without the severe amyloid angiopathy that characterizes other mutations localized within the $A \beta$ sequence. The disease shows memory impairment at early onset -mean age 57 years- with progressive cognitive decline rather than stroke. The parenchymal compromise is similar (if not identical) to that in $A D$, including the presence of parenchymal plaque deposits in association with dystrophic neurites and neurofibrillary tangles. ${ }^{10,11}$ In this case the genetic defect, originating in an $A$ to $G$ transition at codon 693, translates into a single amino acid substitution Glu to Gly at position 22 of $A \beta$ generating the so-called Arctic $A \beta$ variant ( $A \beta E 22 G)$.

A familial form of $A D$ present in Flemish patients originates in a different mutation at codon 692, a C to G transversion, resulting in Ala to Gly substitution at position 21 of $A \beta(A \beta A 21 G)$. The patients exhibit cerebral hemorrhages with progressive dementia and AD-like pathology developing in survivors of the multiple hemorrhagic episodes. ${ }^{7}$ Affected brains demonstrate diffuse cortical atrophy, an abundance of vascular and parenchymal $A \beta$ deposits, and neurofibrillary tangles. Whereas some of the cases present with lobar intracerebral hemorrhage, other members developed presenile dementia. Vascular amyloid is widespread in leptomeningeal and cortical vessel walls, including capillaries. Although diffuse plaques are present, there is a predominance of mature plaques, typically surrounded by $\tau$-reactive dystrophic neurites. Remarkably, these plaques are mostly of perivascular or vasocentric nature appearing to radiate from the affected vessel, a feature that suggests that the AD pathology might be a secondary consequence to CAA. Also presenting with severe vascular compromise in association with compact plaques and neurofibrillary tangles is the $G$ to $A$ mutation occurring at position $42-\mathrm{A} \beta \mathrm{A} 42 \mathrm{~T}$ - found in an Italian and a Spanish kindreds. ${ }^{15}$ The normal architecture of leptomeningeal arteries and small parenchymal vessels in the cere- 
bral hemisphere and cerebellum is severely disrupted by amyloid deposition, presenting thickening and double barreling of the walls, loss of smooth muscle cells, and narrowing of the lumina.

Additional APP mutations have been recently discovered through DNA sequencing and although thus far neuropathological information is not available, their clinical manifestations correlate with early onset familial AD. These include $\mathrm{A} \beta \mathrm{H} 6 \mathrm{R}$ present in a family from the United Kingdom $^{5}$ and $A \beta D 7 N$ found in a Japanese-Tottori pedigree in patients showing no signs of vascular involvement either clinically or neuroradiologically. ${ }^{6}$ A deletion mutation (E693 $\Delta$ ), which results in a variant-A $\beta$ lacking glutamate at position 22, was reported also in Japan in patients showing Alzheimer's-type dementia. ${ }^{12}$ The mutation results in a variant-A $\beta$ with enhanced intracellular accumulation of peptide oligomers in endoplasmic reticulum, Golgi apparatus, early and late endosomes, lysosomes, and autophagosomes. ${ }^{20}$ Consistent with the nonfibrillogenic property of E22 $\Delta$, a very low amyloid signal was observed in positron emission tomography using Pittsburgh compound-B. ${ }^{12,21}$ The latest intra-A $\beta$ mutation reported consists of an Ala-to-Val substitution at residue $2(\mathrm{~A} \beta \mathrm{A} 2 \mathrm{~V})$ that leads to $\mathrm{AD}$ only in the homozygous state. The genetic defect induces a very aggressive early-onset phenotype with established behavioral changes and cognitive deficits at very early age evolving toward severe dementia with spastic tetraparesis, and complete loss of autonomy in about 8 years. Notably the disease affected two homozygous siblings of the family, whereas six relativesaged between 21 and 88 years-who carried the mutation in the heterozygous state, were not affected, as deduced by their neuropsychological assessment. ${ }^{4}$

Members of an lowa pedigree of German descent are carriers of the only APP mutation reported at codon 694, a $G$ to $A$ transition, which predicts a substitution of Asp for Asn at position 23 of $A \beta(A \beta D 23 N) .{ }^{13}$ Patients develop early onset, progressive, AD-like dementia with cerebral atrophy, leukoencephalopathy, and occipital lesions constituted by calcified amyloid-laden meningeal vessels. Although small hemorrhages could be identified by magnetic resonance imaging and postmortem examination, no episodes of clinically manifest intracerebral hemorrhage have been reported. In contrast, a second family from Spain carrying the same mutation is associated with symptomatic cerebral hemorrhage in most of the affected members ${ }^{22}$ suggesting that the presence of the mutation is not in itself sufficient for the induction of a specific clinical phenotype, and that other still undefined factors contribute to the diverse clinical presentation. The neuropathological features of lowa cases notably resemble our findings-predominant CAA, extensive preamyloid pathology, hippocampal neurofibrillary tangles but very few or no neuritic plaques - in a non-A $\beta$ cerebral amyloidosis associated with dementia in a Danish kindred, ${ }^{23}$ challenging the importance of neuritic plaques as critical components for the development of AD-like pathology and dementia. ${ }^{24}$

The biochemical composition of the $A \beta$ lesions in FAD cases associated with $A \beta$ genetic variants has been assessed in only a few instances, the Dutch deposits being perhaps the most thoroughly studied. ${ }^{25,26}$ Herein, we present data indicating that $A \beta$ deposits in carriers of the FAD lowa variant are complex mixtures of mutated and nonmutated $A \beta$ species ( $A \beta 23 N$ and $A \beta 23 D$ ) with very diverse solubility, highly heterogeneous at both $\mathrm{N}$ - and C-termini and exhibiting partial isomerization of Asp residues at positions 1, 7 and 23. Complementary in vitro studies using multiple synthetic homologues argue that the exacerbated mechanism of fibrillization is primarily driven by the mutation whereas the presence of posttranslationally modified isoAsp residues only add a modest contribution to the wild-type $A \beta 40$ aggregation proclivity. Overall, the present biochemical data indicates that the $A \beta$ species composing the lesions certainly contain imprints of amyloid clearance mechanisms and of the putative enzymatic pathways involved.

\section{Materials and Methods}

\section{Materials}

Monoclonal antibodies 4G8 and 6E10 were purchased from Covance (Princeton, $\mathrm{NJ}$ ); rabbit polyclonal anti$A \beta 40$ and anti-A $\beta 42$ as well as paramagnetic beads precoated with anti-rabbit or anti-mouse IgG (Dynabeads M-280) were obtained from Invitrogen (Carlsbad, CA). Sequencing-grade trypsin-pretreated with L-(tosylamido-2-phenyl) ethyl chloromethyl ketone to inhibit contaminating chymotryptic activity-as well as Complete Protease Inhibitors mixture were purchased from Roche (Indianapolis, IN). Microreverse-phase ZipTip C4 columns were purchased from Invitrogen, reverse-phase (RP) columns 214TP52 C4 and 218TP52 C18 from Vydac (Hesperia, CA) and Aquasil C18 columns from Thermo Electron (Bellefronte, PA). SDS-OUT was from Pierce (Rockford, IL), Isoquant Isoaspartate detection kit from Promega (Madison WI), and all chemicals from SigmaAldrich (St. Louis, MO).

Wild-type $A \beta 1-40$ and $A \beta 1-42, A \beta 1-40$ homologues containing two (positions 7 and 23) or three (positions 1 , 7 , and 23) isoAsp residues, as well as the D23N variant A $\beta 40$ peptides with and without isoAsp 1 and 7 were synthesized using $N$-tert-butyloxycarbonyl chemistry by James I. Elliott at Yale University (New Haven, CT). Peptides were purified by RP-high-performance liquid chromatography (HPLC), their molecular masses were corroborated by matrix-assisted laser desorption/ionization time-of-flight mass spectrometry (MALDI-TOF MS), and concentrations assessed by amino acid analysis, as described previously. ${ }^{27}$

\section{Clinical Data}

Frozen brain tissue was obtained at autopsy from two cases (IV-1 and IV-2) of the lowa kindred in which the G to A mutation at codon 694 of APP had been previously identified by DNA sequence analysis, ${ }^{13}$ with pertinent approval from the institutional review board. Case IV-1 was a 68-year-old male with progressive aphasic dementia whose neurological manifestations started at age 48 
with brief episodes of confusion that evolved into cognitive decline at age 53. By age 67, the patient demonstrated severe dementia, speech limitations, myoclonus and short-stepped gait, dying a year later from complications of pneumonia. ${ }^{13}$ Case IV-2 was a 66-year-old male that presented with memory impairment and speech changes at age 58 and subsequently developed aphasia, personality changes, myoclonic jerks, memory disturbance, apraxia, and occasional gait disturbance. He died as a consequence of an accident. Postmortem interval until tissue cryopreservation was 7 hours for case IV-1 and 2 hours for case IV-2. Both cases were found to be heterozygous $\varepsilon 3 / \varepsilon 4$ for the ApoE isoforms. ${ }^{22}$

Frozen brain tissue from three neuropathologically confirmed $A D$ cases were obtained from the SunHealth Institute Brain Bank (Sun City, AZ). Case 1 was a 84 years old $\varepsilon 3 / \varepsilon 4$ female with 14 years of disease duration and Braak stage $\mathrm{VI}$; case 2 was a 74 -year-old $\varepsilon 3 / \varepsilon 4$ male with 12 years of disease duration and Braak stage $\mathrm{VI}$; and case 3 was a 86-year-old $\varepsilon 3 / \varepsilon 4$ female with 9 years disease duration and Braak stage V. Postmortem intervals were 3.5 hours, 2.5 hours and 2.4 hours, respectively.

\section{Immunohistochemical Analysis}

Formalin-fixed paraffin-embedded $7-\mu \mathrm{m}$ brain tissue sections were evaluated for amyloid load by immunohistochemistry (4G8; 1/200) before biochemical analysis. Antigen retrieval was performed by 10-minute pretreatment with 99\% FA before immunostaining. Antibody binding was visualized with $A B C$ complex (DakoCytomation, Carpinteria, $\mathrm{CA}$ ) and color developed with di-aminobenzidine $/ \mathrm{H}_{2} \mathrm{O}_{2}$, followed by hematoxylin counterstaining as described previously. ${ }^{28}$ Thioflavin-S staining of fibrillar amyloid was performed with a $1 \%$ solution ( $\mathrm{w} / \mathrm{v}$ in distilled water) for 30 minutes, followed by differentiation in $80 \%$ ethanol to remove fluorochrome excess. Congo red staining was performed using a $1 \%$ Congo red alkaline solution in $80 \%$ ethanol for 30 minutes, followed by hematoxylin counterstaining, and visualization under polarized light.

\section{Brain Tissue Fractionation}

Nonfibrillar and fibrillar $A \beta$ deposits were sequentially extracted from frozen frontal lobe tissue of both IV-1 and IV-2 cases taking advantage of the differential solubility of preamyloid (usually poorly soluble in PBS solutions but soluble in 2\% SDS) in comparison with amyloid materials, typically soluble in 70 to $98 \%$ formic acid (FA), as described previously. ${ }^{28}$ Frontal cortex was divided into gray and white matters, and leptomeningeal vessels carefully removed and analyzed separately. The bulk of microvessels were collected by subsequent filtration through 70and $30-\mu \mathrm{m}$ nylon meshes and combined with the leptomeningeal vessel fraction for analysis. Typically, $1 \mathrm{~g}$ of vessel-depleted gray matter and $100 \mathrm{mg}$ of vessels-the common average yield for $1 \mathrm{~g}$ of gray matter-were separately homogenized in $5 \mathrm{ml}$ of ice-cold PBS containing Complete Protease Inhibitors, as described previously. ${ }^{28}$
Homogenates were centrifuged (Beckman XL ultracentrifuge, $50.2 \mathrm{Ti}$ rotor; $112,000 \times \mathrm{g} ; 1$ hour, $\left.4^{\circ} \mathrm{C}\right)$, and the PBS extractions of the remaining pellets repeated until the protein content in the fractions, estimated by absorbance at $280 \mathrm{~nm}$, was $<10 \%$ of that of the first extraction (typically approximately six times for gray matter and approximately three times for vessels). The remaining pellets were further subsequently extracted with $2 \%$ SDS $(\mathrm{w} / \mathrm{v}$ in $20 \mathrm{mmol} / \mathrm{L}$ Tris $(\mathrm{pH} 7.4))$ and $70 \%(\mathrm{v} / \mathrm{v}) \mathrm{FA}$ as described previously. ${ }^{28}$ The protein content in each fraction was quantitated using bicinchoninic acid (Pierce) and bovine serum albumin as standard.

\section{Immunoprecipitation and Biochemical Analysis of Extracted $A \beta$ Molecules}

The PBS- and SDS-extracted fractions used for the immunoprecipitation (IP) studies originated from $100 \mathrm{mg}$ of frontal cortex, whereas the FA fractions, enriched in $A \beta$ content, corresponded to the material extracted from only $2.5 \mathrm{mg}$ of frontal cortex. A $\beta$ molecules were immunoprecipitated with paramagnetic beads coated with a combination of $4 \mathrm{G} 8$ and $6 \mathrm{E} 10$ antibodies, as described previously. ${ }^{28,29}$ Bound materials were eluted with either $5 \mu \mathrm{l}$ of acetonitrile-water-trifluoroacetic acid (20:20:1; v/v/v) for $\mathrm{MS}^{30}$ or $10 \mu \mathrm{l}$ of Tris-Tricine sample buffer containing dithiothreitol for Western blot (WB). ${ }^{28}$

\section{Mass Spectrometry Analysis}

Extracted peptide-immunoprecipitates were subjected to MALDI-TOF MS at NYU Protein Analysis Facility on a Micromass Tof-Spec-2E MALDI-TOF mass spectrometer in linear mode using a $10 \mathrm{mg} / \mathrm{ml} \alpha$-cyano-4-hydroxycinnamic acid matrix in $50 \%$ acetonitrile/0.1\% trifluoroacetic acid (TFA) and standard instrument settings. ${ }^{28,31}$ Under these acidic conditions, which render noncovalent binding unobservable, ${ }^{32}$ the different amyloid molecules were detected as monomeric species, independent of their aggregation propensity. Internal and/or external mass calibration was performed using human adrenocorticotropic hormone peptide 18-39 (average mass $=2465.68$ $\mathrm{Da}$ ) and insulin (average mass $=5733.49 \mathrm{Da}$ ) as standards.

\section{WB Analysis}

Samples from each of the extracts, either before (in the case of FA-fractions) or after IP (for SDS- and PBS-solubilized fractions), were separated on $16.5 \%$ Tris-Tricine SDS-PAGE and transferred onto polyvinylidene difluoride membranes (Immobilon-P; Millipore, Bedford, MA). After transference, membranes were boiled for 5 minutes to increase $A \beta$ immunoreactivity, ${ }^{33}$ blocked with $5 \%$ nonfat milk in PBS $(\mathrm{pH} 7.4)$, containing $0.1 \%$ Tween 20 , and probed with $4 \mathrm{G} 8,6 \mathrm{E} 10$, anti-A $\beta 40$ or anti-A $\beta 42$ as primary antibodies ${ }^{28,34}$ followed by incubation with horseradish peroxidase-labeled $\mathrm{F}\left(\mathrm{ab} \mathrm{b}_{2}\right)_{2}$ anti-mouse or anti-rabbit IgG (GE Healthcare Life Sciences, Piscataway, NJ). 
Fluorograms were developed by enhanced chemiluminescence with ECL Western blotting detection reagent (GE Healthcare Life Sciences) and exposed to Hyperfilm Enhanced Chemiluminescence (GE Healthcare Life Sciences). To verify that the WB experimental conditions were able to detect $A \beta 1-42$ oligomeric assemblies, monomeric and oligomerized synthetic A $\beta 1-42$ (200 ng) were electrophoresed, transferred to polyvinylidene difluoride membranes, and probed versus C-terminal specific anti-A $\beta 42$ antibodies under identical conditions as the tissue extracts.

\section{Amino Acid Sequence Analysis}

Automatic Edman degradation was performed on a 494 Procise Protein Sequencer (Applied Biosystems; Foster City, $\mathrm{CA}$ ) in either: i) the prominent $4 \mathrm{kDa} A \beta$ monomeric bands from FA extracts transferred to polyvinylidene difluoride membranes after separation on $16.5 \%$ TrisTricine SDS-PAGE or ii) polybrene-precoated glass filters loaded with HPLC-purified tryptic peptide A $\beta 17-28$, as indicated below, for the identification of the amino acid residue at position 23 .

\section{Analysis of Amino Acid Heterogeneity at Position 23}

FA-fractions containing $10 \mu \mathrm{g}$ of protein were lyophilized, redissolved in $100 \mathrm{mmol} / \mathrm{L}$ Tris $(\mathrm{pH} 8)$, digested with L-(tosylamido-2-phenyl) ethyl chloromethyl ketone-trypsin $(1: 20 \mathrm{w} / \mathrm{w})$ for 2 hours at $30^{\circ} \mathrm{C}$, and the resulting peptides separated by RP-HPLC using a Vydac 218TP52 C18 column and a 25 minutes 1 to $40 \%$ linear gradient of acetonitrile in $0.1 \%$ trifluoroacetic acid (flow rate: 200 $\mu l /$ min), monitoring their elution at $214 \mathrm{~nm}$. Tryptic $A \beta$ fragments in each HPLC fraction were identified by MALDI-TOF MS in linear mode and the fractions containing A $\beta 17-28$ were further characterized by a combination of amino acid sequence analysis and MALDI-TOF in reflectron mode to more accurately distinguish the expected one unit mass difference between tryptic peptides containing either Asp or Asn at position 23. For standardization purposes, parallel trypsin digestion experiments were performed in vitro using synthetic $A \beta 40$ with either Asp or Asn at position 23.

\section{Detection of IsoAsp Residues}

The presence of isoAsp residues was tested via Isoquant Isoaspartate Detection Kit in all tryptic fragments generated from FA-fractions and subsequently separated by RP-HPLC. In brief, lyophilized peptides were dissolved in $100 \mathrm{mmol} / \mathrm{L}$ phosphate buffer ( $\mathrm{pH}$ 6.8) containing 1 $\mathrm{mmol} / \mathrm{L}$ EGTA/0.16\% Triton X-100 and allowed to react with protein L-isoaspartyl methyltransferase, which catalyzes the transfer of a methyl group from S-adenosyl-L methionine (SAM) to isoAsp with the concomitant generation of $S$-adenosyl homocystein $(\mathrm{SAH}){ }^{35}$ The production of SAH was detected by RP-HPLC using a
$150 \mathrm{~mm} \times 4.6 \mathrm{~mm}$ Aquasil C18 column equilibrated in $10 \mathrm{mmol} / \mathrm{L}$ potassium phosphate, $\mathrm{pH} 6.2$ and a 20minute 10 to $40 \%$ linear gradient of methanol (flow rate: $400 \mu \mathrm{l} / \mathrm{min}$ ); elution profiles were monitored by absorbance at $260 \mathrm{~nm}$. Synthetic peptide WAGG-isoD-ASGE and SAH (Promega) were used as positive controls whereas A $329-40$, devoid of any Asp residues, served as a negative control.

\section{In Vitro Fibrillization of $A \beta D 23 N$ and IsoAsp-Containing Synthetic Homologues}

Wild-type $A \beta 1-40$ and homologues containing two (positions 7 and 23) or three (positions 1, 7, and 23) isoAsp residues, as well as the D23N variant peptides with and without isoAsp 1 and 7 were dissolved to $1 \mathrm{mmol} / \mathrm{L}$ in hexafluoro-isopropanol (Sigma-Aldrich), a pretreatment that breaks down $\beta$-sheet structures and disrupts hydrophobic forces leading to monodisperse $A \beta$ preparations. ${ }^{36}$ After 2 hours incubation at room temperature, peptides were lyophilized to remove hexafluoro-isopropanol and thoroughly dissolved to $1.5 \mathrm{mmol} / \mathrm{L}$ in $01 \%$ ammonium hydroxide followed by the addition of deionized water and $2 \times$ concentrated PBS $(\mathrm{pH} 7.4)$ to a final concentration of $1 \mathrm{mg} / \mathrm{ml}$ in $1 \times$ PBS. Reconstituted peptides were incubated at $37^{\circ} \mathrm{C}$ for up to 3 days and the fibrillization profiles assessed by Thioflavin T binding assay as described previously. ${ }^{37}$ Briefly, $6-\mu$ l aliquots of each of the peptide aggregation time-point samples were added to $10 \mu \mathrm{l}$ of $0.1 \mathrm{mmol} / \mathrm{L}$ Thioflavin T (Sigma-Aldrich) and $50 \mathrm{mmol} / \mathrm{L}$ Tris-HCl buffer $(\mathrm{pH}$ 8.5) to a final volume of $200 \mu \mathrm{l}$. Fluorescence was recorded after 300 seconds in a LS-50B luminescence spectrometer (PerkinElmer, Waltham, MA) with excitation and emission wavelengths of $435 \mathrm{~nm}$ (slit width $=10 \mathrm{~nm}$ ) and $490 \mathrm{~nm}$ (slit width = $10 \mathrm{~nm}$ ), respectively, as described previously. ${ }^{38,39}$ Each sample was analyzed in duplicate.

\section{Results}

\section{Main Pathological Features of lowa Variant Cases}

Figure 1 illustrates the extent of $A \beta$ deposition in patients from the lowa pedigree, which is characterized by a profuse cerebrovascular compromise (Figure 1A) and abundant presence of preamyloid deposits (Figure 1, B and $\mathrm{C}$, arrows) with limited fibrillar, compact parenchymal plaques, which, in many instances, are vasocentric (double arrows in Figure 1, B and C). The fibrillar nature of the vascular deposits is highlighted by both Congo red (Figure 1, D and E) and Thioflavin-S (Figure 1F) staining, whereas the high anti- $\mathrm{A} \beta$ parenchymal immunoreactivity in combination with the limited fluorescent signal of the Thioflavin-S illustrates the extent of the predominant diffuse parenchymal deposits. 

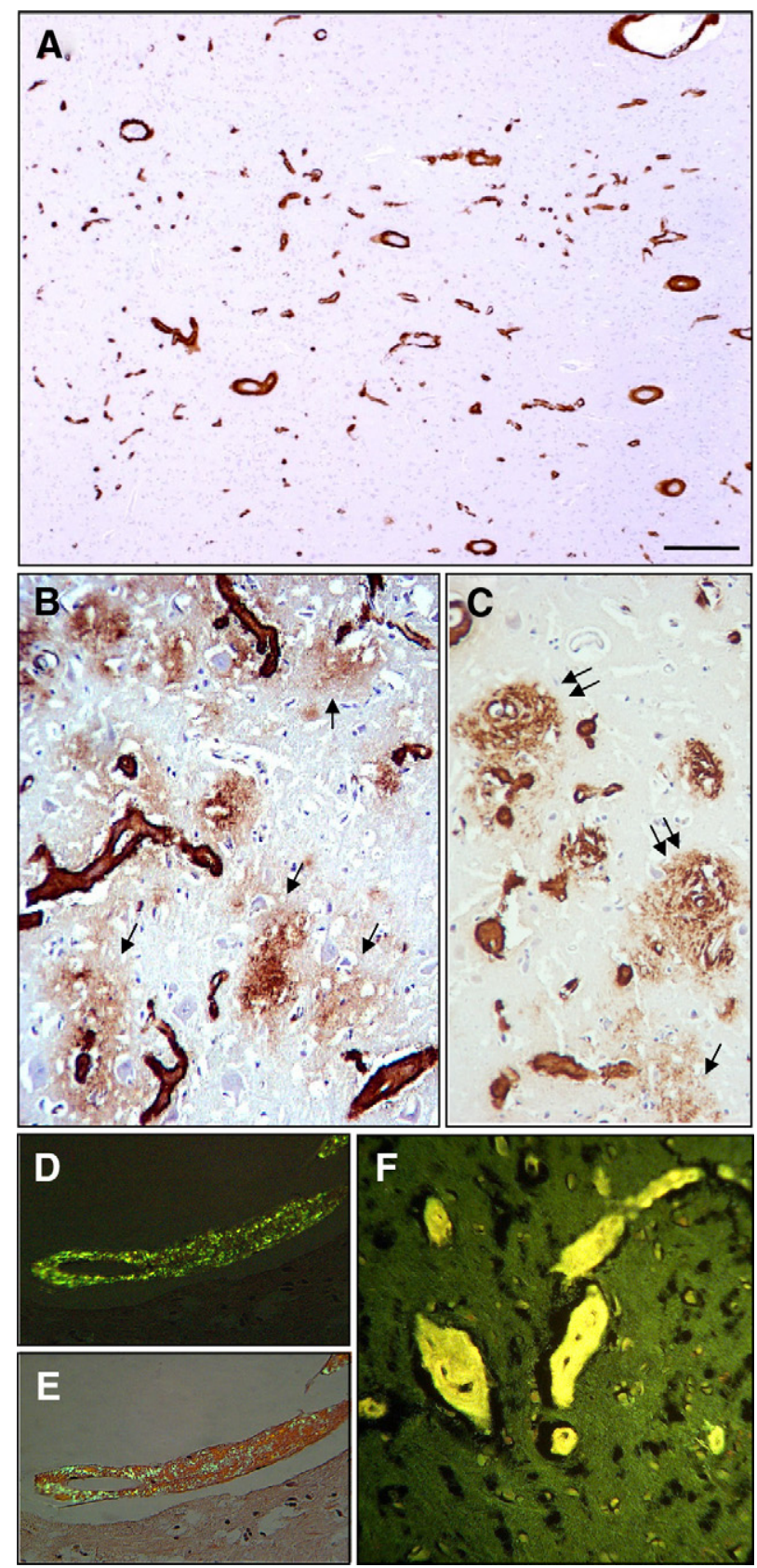

Figure 1. Immunohistochemical analysis of parenchymal and vascular lesions in the Iowa pedigree. Vascular anti-A $\beta$ (4G8) immunoreactivity (A); preamyloid lesions (arrows, B); vasocentric plaques (double arrow, C); Congo red positive, birefringent vascular deposits (D and $\mathbf{E}$ ); and thioflavin $\mathrm{S}$ fluorescent vascular deposits (F). Scale bar represents $200 \mu \mathrm{m}$ in $\mathbf{A}$ and $100 \mu \mathrm{m}$ in $\mathbf{B}-\mathbf{F}$.

\section{Extraction of Soluble and Deposited A $\beta$ Species by Sequential Solubilization}

The biochemical characterization of amyloid deposits was performed in frozen brain tissue obtained at autopsy with short postmortem delay. A $\beta$ species were sequentially extracted following protocols previously developed in our laboratory. ${ }^{28}$ Soluble $A \beta$ peptides are typically recovered in the water-based extracts; oligomeric nonfibrillar $A \beta$ species found concentrated in pre-amyloid lesions are retrieved by detergent-based solutions, whereas the more insoluble fibrillar $A \beta$ is extracted with $F A$

\section{A $\beta$ Species in Water-Soluble Extracts}

SDS-PAGE of the immunoprecipitated PBS-soluble A $\beta$ fraction from case IV-2 brain parenchyma showed mainly monomeric with faint dimeric components, which were immunoreactive with 4G8, 6E10, and anti-A $\beta 40$ but not with anti-A $\beta 42$ (Figure 2A). Monomers appeared as a doublet of which the lower molecular mass band was the major component. MS identified, in addition to the fulllength $\mathrm{A} \beta 1-40, \mathrm{~N}$ - and C-terminally truncated species, particularly at positions 4, 34, and 38 (Figure 2, A and C). Parenchymal extracts from case IV-1 rendered similar results although the $A \beta 4-34$ derivative was predominant over the other species listed in Figure $2 \mathrm{C}$, perhaps reflecting additional proteolytic degradation resulting from the longer postmortem delay. Vascular PBS-extracts (Figure 2B) presented a similar immunoreactivity with 4G8, 6E10, and anti-A $\beta 40$ as the parenchymal extracts but were enriched in $A \beta$ species exhibiting a higher degree of polymerization, whereas immunoreactivity with anti-A $\beta 42$ was also very weak. In addition, most bands in the SDS-PAGE appeared more heterogeneous, suggesting the presence of more than one component. Consistent with these data $A \beta 1-40$ and C-terminally truncated $A \beta 1-38$ species coexisted with other $\mathrm{N}$ - and $\mathrm{C}$-terminally degraded components, as revealed by MS. A $\beta 4-34$ was not obvious in the vessel fraction although $\mathrm{N}$-terminally intact $A \beta 1-34$ was present (Figure 2, B and C). No significant differences between the two cases studied were observed in the vascular $A \beta$ composition either by WB or by MS. Validating the specificity of our detection system and supporting the present finding of a negligible amount of $A \beta 1-42$ in PBS extracts, synthetic $A \beta 1-42$ either in monomeric or oligomeric state was highly immunoreactive with the same C-terminal specific anti-A $\beta 42$ antibody used in Figure 2 (Supplemental Figure 1, see http://ajp.amjpathol.org).

\section{A $\beta$ Species in SDS-Extractable Deposits}

Overall, immunoprecipitated SDS extracts exhibited a higher degree of $A \beta$ polymerization and less heterogeneity than the water-soluble counterparts, a feature also revealed by MS analysis of extracts from AD cases (see Supplemental Figure 2, see http://ajp.amjpathol.org). In parenchyma, monomers, dimers, and higher-order aggregates were labeled by 4G8, 6E10, and anti-A $\beta 40$. As happened with the PBS-soluble fractions, parenchymal SDS extracts were weakly immunoreactive with anti-A $\beta 42$. Monomers also appeared as doublets like in the PBS extracts, although in the SDS fractions the upper band seemed to be the main component of the doublet (Figure 3A). Consistent with the presence of more than one band in the monomeric component, MS identified full-length $A \beta 1-40$ as well as $N$ - and C-terminal truncated species degraded at positions 2, 4, 37, and 38 (Figure $3, \mathrm{~A}$ and $\mathrm{C}$ ).

In the vascular fractions, SDS-soluble $A \beta$ was more abundant than in parenchymal extracts and vastly polymer- 
A

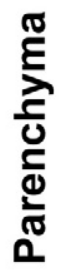

B
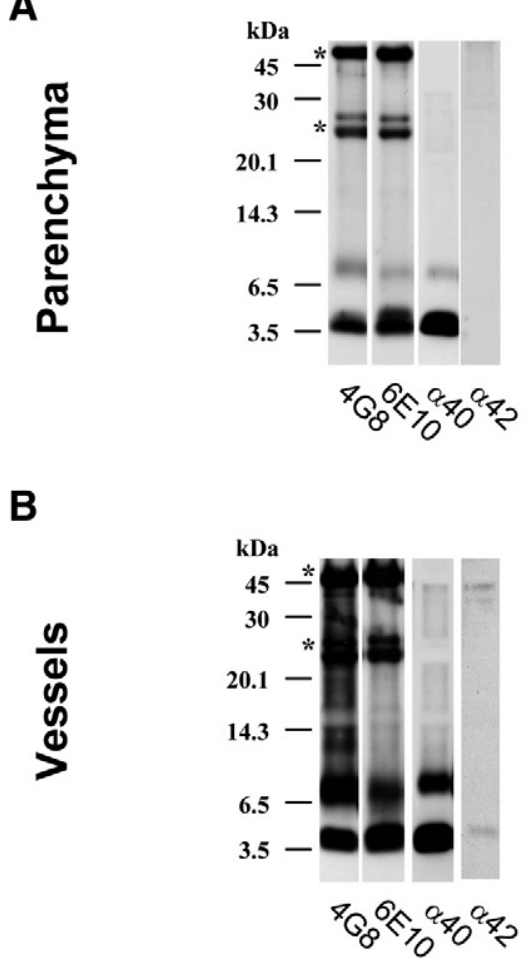
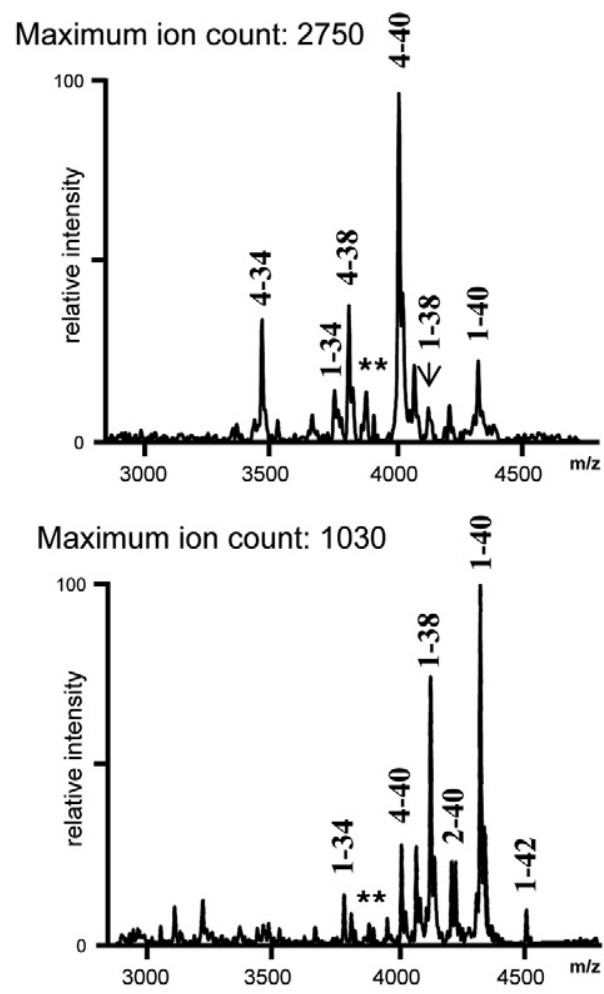

\begin{tabular}{|c|c|c|c|c|c|c|c|c|c|c|c|c|}
\hline \multirow{4}{*}{$\begin{array}{c}\text { experimental } \\
\text { average mass }\end{array}$} & regions & case & $5-34$ & $4-34$ & $1-34$ & $4-38$ & $4-40$ & $1-38$ & $2-40$ & $1-39$ & $1-40$ & $1-42$ \\
\hline & parenchyma & IV-2 & $(-)$ & 3472.5 & 3787.1 & 3817.4 & 4015.3 & 4132.5 & 4216.2 & $(-)$ & 4330.0 & $(-)$ \\
\hline & \multirow{2}{*}{ vessels } & IV-1 & $(-)$ & $(-)$ & 3788.0 & $(-)$ & 4015.9 & 4132.0 & 4215.1 & 4230.7 & 4329.8 & 4514.3 \\
\hline & & IV -2 & $(-)$ & $(-)$ & 3787.8 & 3816.8 & 4015.2 & 4132.1 & 4215.3 & 4230.5 & 4330.8 & 4513.7 \\
\hline \multicolumn{3}{|c|}{ theoretical average mass of $A \beta W T[M+H]$} & 3325.7 & 3472.9 & 3788.2 & 3817.3 & 4015.6 & 4132.6 & 4215.8 & 4231.7 & 4330.9 & 4515.1 \\
\hline
\end{tabular}

Figure 2. WB and MS analysis of PBS-extracted A $\beta$. A $\beta$ species retrieved from fractions extracted from 100 mg of microvessel-depleted frontal cortex (A); 10 mg of microvessels and leptomeningeal vessels recovered from $100 \mathrm{mg}$ of frontal cortex $(\mathbf{B})$. C: Theoretical and experimental $m / z$ values. WB: $*$ indicates residual Ig light and heavy chains from the IP. MS: ** illustrates nonspecific peaks also present in negative controls.

ized. Antibodies 4G8, 6E10, and anti-A $\beta 40$ extensively labeled these oligomeric species whereas anti-A $\beta 42$ highlighted only a signal of $A \beta 42$ monomers. MS data indicated the presence of $A \beta 1-40$ coexisting with $A \beta$ species truncated at positions 2, 4, and 38 (Figure 3, B and C). Consistent with the faint band in the WB, $A \beta 1-42$ was detectable in the IP/MS at lower ratio than in comparable SDS extracts from $A D$ cases analyzed by the same procedure (Supplemental Figure 2, see http://ajp.amjpathol.org). Variations between cases IV-1 and IV-2 were not evident.

\section{A $\beta$ Species in FA-Extractable Deposits}

FA-extracts from both parenchyma (Figure $4 A$ ) and vessels (Figure $4 \mathrm{~B}$ ) contained highly polymerized $A \beta$. Consistent with the pathological features of lowa cases-extensive CAA in almost complete absence of mature plaques - the amount of $A \beta$ recovered in the FA vessel fractions was significantly more abundant than in the parenchymal extracts. Although the degree of $A \beta$ polymerization was similar to that in SDS extracts, the total amount of $A \beta$ retrieved with FA (>50-fold higher) allowed visualization of $A \beta$ signals by
WB without prior IP. C-terminal specific labeling by anti$A \beta 40$ or anti-A $\beta 42$ indicated that most of the deposited $A \beta$ consisted of $A \beta x-40$ species with an almost negligible contribution of $A \beta x-42$ components. MS data identified $A \beta 1-40$ as well as $\mathrm{N}$ - and $\mathrm{C}$-terminal truncated forms, such as $A \beta 2-40, A \beta 4-40, A \beta 2-37$, and $A \beta 1-38$ in both parenchyma and vessels. MS signal of $A \beta 11-42$ bearing pyroglutamate at position $11(\mathrm{~A} \beta 11-42 \mathrm{pE})$ was detected in parenchymal deposits, whereas $A \beta 1-42$ was also identified in both parenchymal and vascular extracts. Similar $A \beta$ species were obtained from both cases studied (Figure 4C). Comparison with FA extracts from AD cases further corroborated the minor contribution of $A \beta 42$ to the amyloid deposits in the lowa cases (Supplemental Figure 2, see http://ajp.amjpathol.org).

\section{Coexistence of Wild-Type and ABD23N Species in lowa-Amyloid Deposits}

The existence of heterogeneity at position 23 was tested in FA fractions, which contained the bulk of the extracted 

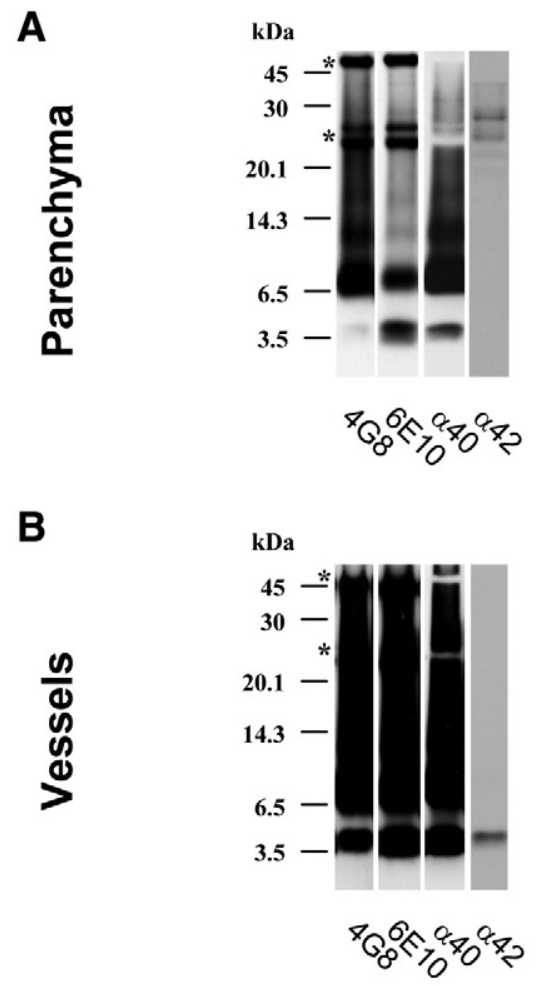
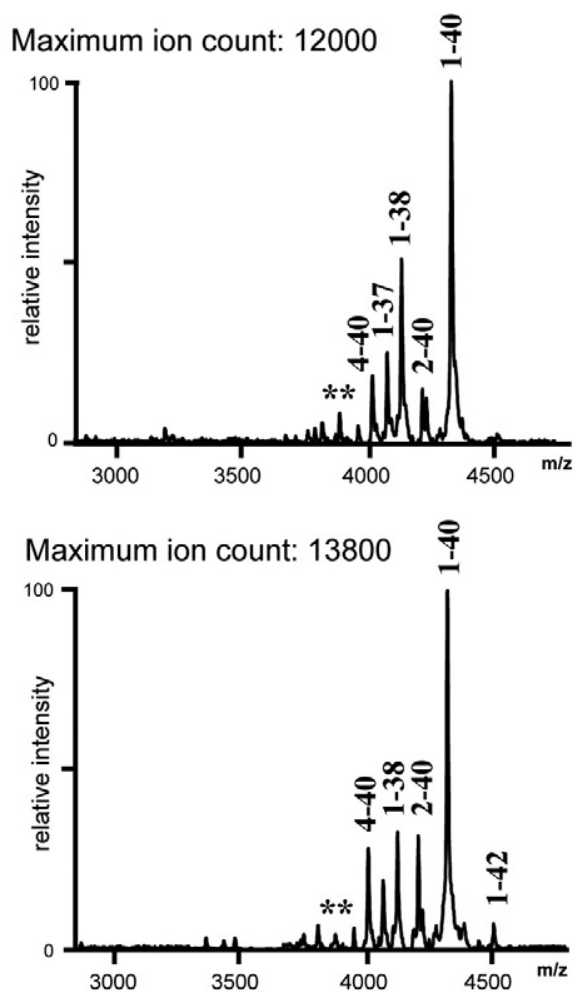

\begin{tabular}{|c|c|c|c|c|c|c|c|c|c|}
\hline \multirow{4}{*}{$\begin{array}{l}\text { experimental } \\
\text { average mass }\end{array}$} & regions & case & $4-40$ & $1-37$ & $1-38$ & $2-40$ & $1-39$ & $1-40$ & $1-42$ \\
\hline & parenchyma & IV-2 & 4016.3 & 4074.7 & 4131.4 & 4215.1 & 4230.1 & 4330.0 & 4514.8 \\
\hline & \multirow{2}{*}{ vessels } & IV-1 & 4015.0 & $(-)$ & 4130.5 & 4213.9 & $(-)$ & 4328.6 & 4512.9 \\
\hline & & IV-2 & 4016.0 & 4074.9 & 4132.0 & 4215.0 & 4231.2 & 4330.6 & 4514.4 \\
\hline
\end{tabular}

Figure 3. WB and MS analysis of SDS-extracted A $\beta$. A $\beta$ species retrieved from $100 \mathrm{mg}$ of microvessel-depleted frontal cortex (A); 10 mg of microvessels and leptomeningeal vessels recovered from 100 of $\mathrm{mg}$ frontal cortex (B). C: Theoretical and experimental $\mathrm{m} / z$ values. WB: * indicates residual Ig chains. MS: ** indicates nonspecific peaks appearing in the negative controls.

A $\beta$. MS in linear mode was not useful to distinguish the one mass unit difference between wild-type and D23N; therefore, FA-extracted molecules as well as synthetic homologues of both peptides were subjected to trypsin digestion and the molecular masses of the corresponding RP-HPLC purified peptides was assessed by MS in reflectron mode. As expected by the presence of two Lys and one Arg residues, trypsin cleavage generated four peptides (Figure 5A). Proteolytic fragments A $\beta 6-16$ (T2) and $A \beta 1-5$ (T1) eluted from the RP column at the beginning of the gradient (14 and 15\% acetonitrile, respectively), $A \beta 17-28$ (T3) was retrieved at $30 \%$ acetonitrile, whereas $A \beta 29-40$ was recovered at the end of the gradient (36\% acetonitrile). The main difference in the tryptic fingerprints of extracted and synthetic $A \beta$ digests was observed in $A \beta 17-28$ (T3) (Figure 5B). In the case of the synthetic homologues, T3 showed different retention time depending on whether the peptides contained the mutated (Asn) or the wild-type (Asp) sequence (T3a and T3b, respectively). In the lowa extracted samples, T3 appeared as a doublet with retention times compatible with the presence of both $\mathrm{T} 3 \mathrm{a}$ and $\mathrm{T} 3 \mathrm{~b}$ at $\mathrm{a} \sim 1: 1$ ratio; amino acid sequence analysis of both peaks corroborated the coexistence of Asp and Asn at position 23 (Supplemental Table 1, see http://ajp.amjpathol.org). MS in reflectron mode confirmed that $\mathrm{T} 3 \mathrm{a}$ originated from $\mathrm{A} \beta \mathrm{D} 23 \mathrm{~N}$ (experimental mass $=1324.60$; theoretical mass $=1324.69)$, whereas T3b resulted from the wildtype-A $\beta$ D23 peptide (experimental mass = 1325.75; theoretical mass $=1325.67$ ) (Figure $5 \mathrm{C}$ ). Identical MS results were obtained for the $A \beta 17-28$ peptides derived from the synthetic homologues (data not shown). Similar heterogeneity was present in both parenchyma and vessels in the two cases studied.

\section{Aspartic Acid Isomerization at Positions 1, 7 , and 23 of $A \beta$}

Although amino acid sequence analysis of T3a and T3b tryptic peptides established the presence of both Asp and Asn at position 23, recovery calculations (Supplemental Table 1, see http://ajp.amjpathol.org) indicated that the yield of Asp23 was lower than that of Asn23 
A

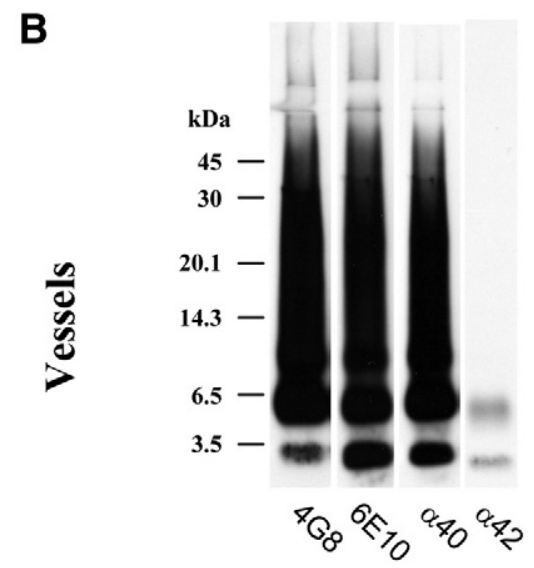

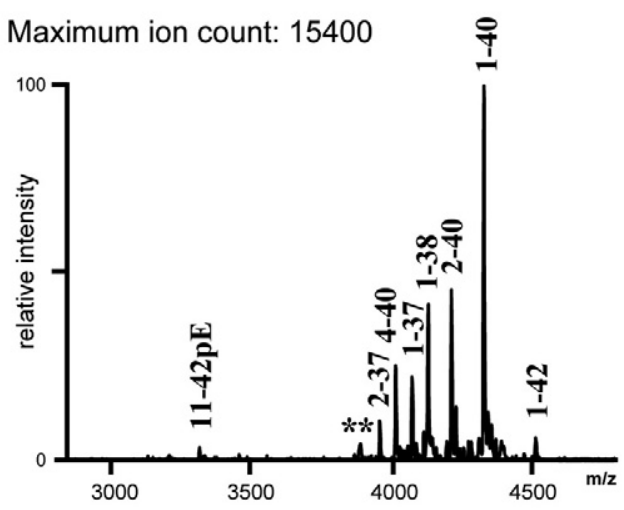

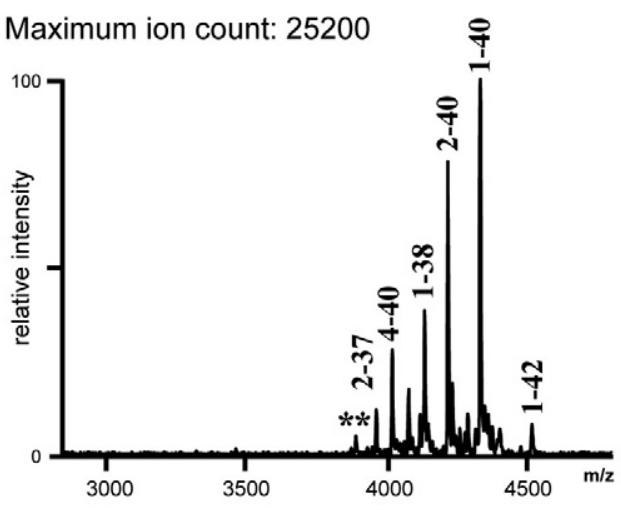

\begin{tabular}{|c|c|c|c|c|c|c|c|c|c|c|c|c|}
\hline \multirow[t]{2}{*}{ C } & regions & case & $\begin{array}{c}11-42 \\
p E\end{array}$ & $2-37$ & $4-40$ & $1-37$ & $1-38$ & 4.42 & $2-40$ & $1-39$ & $1-40$ & $1-42$ \\
\hline & \multirow{2}{*}{ parenchyma } & IV-1 & 3318.2 & 3959.6 & 4016.6 & 4075.1 & 4132.1 & 4199.1 & 4215.3 & 4231.1 & 4330.5 & 4514.8 \\
\hline \multirow{3}{*}{$\begin{array}{l}\text { experimental } \\
\text { average } \\
\text { mass }\end{array}$} & & $\mathrm{IV}-2$ & 3318.0 & 3960.2 & 4016.0 & 4075.3 & 4132.3 & $(-)$ & 4215.2 & 4231.4 & 4329.9 & 4514.4 \\
\hline & \multirow{2}{*}{ vessels } & IV-1 & $(-)$ & 3960.2 & 4016.8 & 4075.2 & 4132.2 & $(-)$ & 4215.1 & 4230.7 & 4330.0 & 4514.4 \\
\hline & & $\mathrm{IV}-2$ & $(-)$ & 3959.4 & 4016.0 & 4074.0 & 4131.4 & $(-)$ & 4214.4 & 4230.5 & 4329.9 & 4513.4 \\
\hline \multicolumn{3}{|c|}{ theoretical average mass $A \beta 23 \mathrm{~N}[\mathrm{M}+\mathrm{H}]$} & 3317.9 & 3959.5 & 4014.6 & 4074.6 & 4131.6 & 4198.8 & 4214.8 & 4230.7 & 4329.9 & 4514.1 \\
\hline \multicolumn{3}{|c|}{ theoretical average mass $A \beta W T[M+H]$} & 3318.9 & 3960.5 & 4015.6 & 4075.6 & 4132.6 & 4199.8 & 4215.8 & 4231.7 & 4330.9 & 4515.1 \\
\hline
\end{tabular}

Figure 4. WB and MS analysis of fibrillar A $\beta$ deposits. A: Parenchymal FA extracts of frontal cortex obtained from either 0.25 or 2.5 mg of tissue for WB and MS, respectively. B: FA extracts from leptomeningeal and microvessel fractions obtained from either 0.025 - or 0.25 -mg vessels for WB and MS, respectively; C: Theoretical and experimental $\mathrm{m} / z$ values. MS: ${ }^{* *}$ indicates nonspecific peaks appearing in the negative controls.

(Asn23: Asp23 ratio $=2.8: 1$ for case IV-1 and 1.3: 1 for IV-2), whereas as judged by the data from RP-HPLC fingerprinting, the ratio appeared to be $\sim 1: 1$ (Figure $5 \mathrm{~B}$ ). This discrepancy suggested the likely existence of isoAsp with the concomitant blocking of the Edman degradation chemistry and subsequent decrease in the yield of the amino acid sequence data. On the basis of the sequence recovery, it was estimated that $\sim 65$ and $\sim 25 \%$ of the Asp23 was blocked in cases IV-1 and IV-2, respectively. Similarly, when directly analyzing the $\mathrm{N}$-terminal sequence recovery of the FA-extracts (Supplemental Table 2, see $h t t p: / / a j p . a m j p a t h o l . o r g)$, the presence of three main sequences was identified corresponding to species starting at position 2, 4 and 1. On the basis of the amino acid recovery for both IV-1 and IV-2 cases, a ratio of $\sim$ 4:2:1 for species starting at positions 2, 4, and 1, respectively, was estimated. Although $A \beta$ species starting at residues 2, and 4 were identified in the MS data shown in Figure 4, full-length $A \beta 40$ was overrepresented, suggesting that a proportion of the N-termini were unable to undergo Edman degradation likely due to the presence of isoAsp, as reported in early biochemical studies ${ }^{40,41}$ for position 1 in sporadic AD brains.

To verify the presence of isoAsp at all of the putative Asp sites, tryptic digestion products of FA extracts purified by RP-HPLC were subjected to enzymatic methylation using isoaspartyl-methyl-transferase, which specifically catalyzes the methylation of isoAsp at the $\alpha$-carboxyl position in the presence of $S$-adenosyl-L methionine. As a result of the methyl transfer, the latter generates $\mathrm{SAH}$ - which can be identified by RP-HPLC- in a 1:1 ratio with respect to the number of isoAsp residues present within the molecule. Figure 5D illustrates the RP-HPLC profiles resulting from the analysis of $\mathrm{SAH}$ in the respective tryptic pep- 


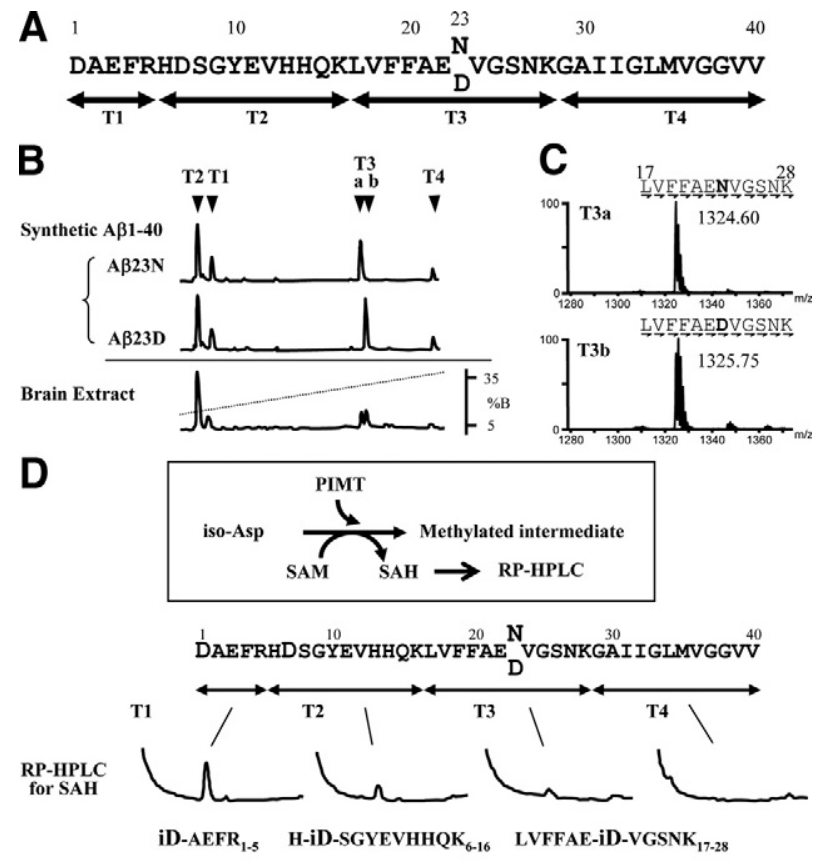

Figure 5. Biochemical heterogeneity of amyloid lesions. A: Location of Iowa mutation on the $\mathrm{A} \beta 1-40$ sequence and the T1, T2, T3, and T4 tryptic peptides; B: RP-HPLC of tryptic digests of wild-type (D23) and variant (N23) synthetic homologues, as well as of Iowa FA-extracts; C: MALDI-TOF MS of T3a and $\mathrm{T} 3 \mathrm{~b}$ in reflectron mode. Monoisotopic mass of protonated T3 from N23 is 1324.69 Da and from D23 is 1325.67; D: Detection of isoAsp residues. Inset: Schematic representation of enzymatic reaction for isoAsp identification. RP-HPLC profiles indicate the presence of $S$-adenosyl-homocysteine in tryptic fragments T1, T2, and T3 but not in T4.

tides. SAH peaks were observed in T1, T2, and T3 fractions, corroborating the presence of isoAsp at positions 1, 7, and 23. In contrast, SAH was not evident in T4 fractions lacking Asp residues.

\section{Effect of Aspartic Acid Isomerization and D23N Mutation on A $\beta$ Fibrillogenesis}

Figure 6 illustrates the kinetics of thioflavin T binding of synthetic wild-type $A \beta 1-40$ and homologues containing two (positions 7 and 23) or three (positions 1, 7, and 23) isoAsp residues as well as the $\mathrm{D} 23 \mathrm{~N}$ variant peptides with and without isoAsp 1 and 7 . Wild-type $A \beta 40$, as previously described, ${ }^{27}$ showed low tendency to form fibrillar/protofibrillar assemblies with thioflavin T fluorescence values that remained low for the 3-day duration of the experiment. The presence of two or three isoAsp residues had an enhancing - albeit modest_effect on fibrillization, without significantly affecting the lag phase and reaching only a slightly higher end-point after 3-days incubation. The combined presence of the D23N mutation together with isoAsp residues at positions 1 and 7 , as found in the lowa brain deposits, strikingly changed the peptide behavior with respect to the wild-type counterpart; the fibrillization kinetics was dramatically accelerated, showing $>20$-fold higher fluorescence values than the wild-type peptide after only 30 minutes of incubation, and reaching maximum fibrillization at 24 hours. Notably,

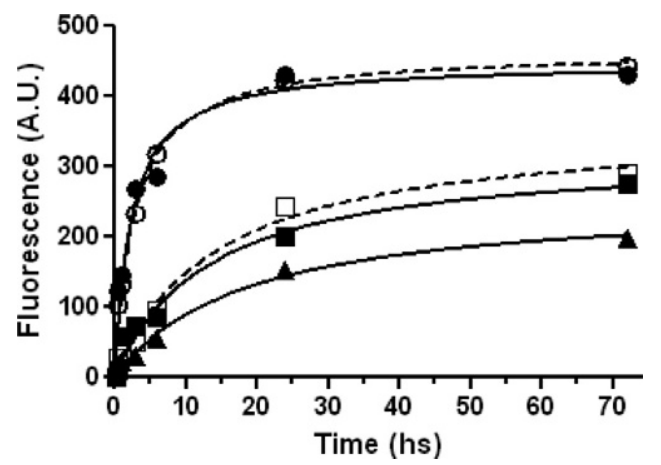

Figure 6. Effect of Asp acid isomerization and $\mathrm{D} 23 \mathrm{~N}$ mutation on $\mathrm{A} \beta$ fibrillogenesis assessed by thioflavin-T binding. Fluorescence evaluation (excitation/emission wavelengths $435 / 490 \mathrm{~nm}$, respectively) of Thioflavin T binding assay of the samples collected at the different time points during the 3-days duration of the experiments was performed as described in Materials and Methods. The data are representative of three independent experiments open circles, $\mathrm{A} \beta \mathrm{D} 23 \mathrm{~N}$ isoAsp1,7 (solid line); closed circles, $\mathrm{A} \beta \mathrm{D} 23 \mathrm{~N}$ Asp1,7 (dash line); closed squares, $\mathrm{A} \beta 40$ isoAsp7, 23 (solid line); open squares, $\mathrm{A} \beta 40$ isoAsp1,7, 23 (dash line); triangles, wild-type $\mathrm{A} \beta 40$ (solid line).

under the conditions tested, the fibrillization kinetics seemed to be primarily driven by the presence of the D23N mutation. Thioflavin-T experiments with the A $\beta D 23 N$ homologue bearing Asp residues at positions 1 and 7 rendered overlapping curves with the mutant counterpart containing isoAsp residues.

\section{Discussion}

Detailed immunohistochemical analysis of the $A \beta$ deposits in the lowa variant of AD showed extensive vascular compromise coexisting with pre-amyloid deposits and abundant neurofibrillary tangles in the presence of remarkably few mature plaques with no obvious evidence of intracellular $A \beta .^{2}$ The distribution of $A \beta$ species was notable for the unusual extent of $A \beta 40$ deposition in the parenchymal lesions in clear contrast with the typical $A \beta 42$ predominance in sporadic AD parenchymal plaques, prevalence that was evident in confocal microscopy colocalization studies and further corroborated by quantitative evaluation via ELISA of both components in brain homogenates. ${ }^{13,42}$ The present studies corroborated these findings and biochemically characterized for the first time the $A \beta$ composition of both parenchymal and vascular lesions using a combination of IP, WB, MS, and amino acid sequence analysis following tissue dissection and separation of vessels from parenchyma. Reflecting the complexity of the lesions, fibrillar as well as nonfibrillar components of the lowa $A \beta$-peptidome were highly heterogeneous at both $\mathrm{N}$ - and C-terminal ends and exhibited a diverse degree of polymerization, going well beyond the classical dichotomy $A \beta 40-A \beta 42$. Whereas amyloid deposits were highly aggregated, N- and Cterminal heterogeneity-although present-was not as extensive as that observed in the non-fibrillar $A \beta$ deposits. PBS-extractable materials, in particular, were rich in $\mathrm{N}$ - and C-terminal truncated species while showing a less pronounced aggregation. These extracts were enriched in $A \beta$ peptides truncated at Glu3-Phe4 and/or Leu34Met35 peptide bonds, whereas many of these species 
were not even detectable in SDS and FA extracts. Notably, cleavages at these positions are not specific features of the lowa patients. Both truncations were identified in our studies of brain deposits from sporadic $A D$ cases and have also been reported in sporadic CAA, Lewy Body disease, sporadic and familial $A D$ with presenilin-1 Ile83Met84 deletion mutation, as well as in familial Danish dementia ${ }^{43}$ - a cerebral amyloidosis with deposits of two unrelated subunits, $A D a n$ and $A \beta^{44}$-suggesting the existence of common proteolytic pathways for $A \beta$ deposits.

The existence of these $\mathrm{N}$ - and $\mathrm{C}$-terminally degraded species in the lowa deposits correlates not only with findings in $A D$ and other forms of cerebral amyloidosis presenting with $A \beta$ deposition as reported by our group ${ }^{25,28,43}$ and others, ${ }^{40,45,46}$ but also by proteomic data demonstrating numerous $A \beta$ fragments in AD cerebrospinal fluid, ${ }^{47,48}$ many of which are common with the species found in the present study. The high solubility exhibited by many of these truncated $A \beta$ derivatives together with their absence in fibrillar deposits likely reflects the result of clearance mechanisms questioning their importance in the amyloidogenesis process. In this sense, numerous enzymes have been postulated to participate in brain $A \beta$ catabolic pathways including neprylisin, endothelin-converting enzyme, insulin-degrading enzyme, plasmin, $\beta$-Site of APP Cleaving Enzyme (BACE-1), and matrix metalloproteases (MMPs) among others (reviewed in Refs. 49 and 50). Current knowledge attributes to these enzymes the maintenance of the balance between $A \beta$ production and catabolism, and it has been postulated that defective degradation contributes to the $A \beta$ accumulation associated with disease. Potential candidates for the major cleavage products present in lowa cases are insulin-degrading enzyme, ${ }^{51}$ neprylisin, ${ }^{52}$ and tripeptidyl peptidase-153 for peptide bond Glu3-Phe4, while the cleavage at Leu34-Met35 peptide bond likely originates by the action of $\mathrm{MMPs}^{54}$ or cathepsin $\mathrm{D}^{55}$ Fragments ending at positions 37 and 38 likely result from the action of $\gamma$-secretase, known to exhibit activity at multiple $A \beta$ C-terminal sites. ${ }^{56-58}$

Co-deposition of mutated and non-mutated species has been also observed in other cerebral amyloidosis, including the Dutch familial form of $A D^{26}$ and prion diseases, ${ }^{59}$ as well as in systemic forms of amyloidosis. ${ }^{60-64}$ It is likely that the deposition of the respective mutated species exerts a seeding effect -or a conformational mimicry-enhancing the fibrillization and subsequent codeposition of the wild-type counterparts, as previously proposed. ${ }^{28,65,66}$ Contributing to the complexity of the lesions in lowa-variant cases, deposited $A \beta$ species showed additional heterogeneity with a significant proportion of the peptides containing isoAsp at residues 1, 7, and 23. This posttranslational modification has only been demonstrated at the biochemical level at $A \beta$ residues 1 and 7 in AD cases. ${ }^{40,41}$ However, immunohistochemical analysis using site-specific antibodies suggested, in conjunction with isoAsp 1 and 7 the additional presence of isoAsp23 in sporadic $A D^{67}$ as well as in the lowa-FAD ${ }^{42}$, although at a lower ratio than in the other positions. Our studies demonstrate that $\sim 10$ to $30 \%$ of the total deposited molecules in lowa brain tissues contain isoAsp23.
The mechanisms leading to the elevated isoAsp23 content in the lowa variant remain to be determined but it is likely to originate in nonenzymatic Asn deamidation, which typically results in $\sim 30$ times faster formation of isoAsp than isomerization at Asp residues. ${ }^{68}$ Thus, the higher content of isoAsp23 in lowa cases compared with $A D$ may very well result from the presence of the mutation itself, which provides a more efficient starting point, Asn, for isoAsp formation. It is interesting to note that, in general terms, Asn deamidation with the consequent generation of isoAsp -in addition to other post translational modifications-is associated with conformational changes and aging. ${ }^{69,70}$ In this sense, not only do $A \beta$ molecules bearing isoAsp23 show enhanced in vitro fibrillization kinetics compared with wild-type molecules, ${ }^{67}$ but the presence of isoAsp at positions 1 and 7 typically translate into a decreased sensitivity for proteolytic degradation, ${ }^{71}$ features that may well contribute to the aggressiveness of the lowa phenotype. The in vitro fibrillization analysis described herein clearly demonstrates that, despite the modest enhancing effect induced by the presence of isoAsp residues, the accelerated kinetics is primarily driven by the presence of the Asn mutation at position 23, which not only exacerbates the fibrillogenic propensity of the peptide but dramatically shortens the lag-phase of the conformational change.

The amino acid change present in lowa tissues is similar to that of the Dutch mutant; in both cases there is a loss of a negatively charged residue occurring at the immediate location in the molecule (D23N versus E22Q). Perhaps as a result of these similar changes, both D23N and E22Q synthetic homologues display high content in $\beta$-sheet secondary structure and rapidly assemble in solution to form typical amyloid fibrillar assemblies. ${ }^{72}$ These conformational properties appear to confer, in turn, to both peptides enhanced toxicity for cerebrovascular smooth muscle cells. ${ }^{9,72,73}$ Notably, peptides carrying both mutations showed enhanced fibrillogenic properties compared with each of the single mutated peptides and exhibited more than double toxicity for cerebrovascular cells. ${ }^{72}$ However, despite the structural similarities between the lowa- and Dutch- $A \beta$ peptides, there are clear clinical differences in the in vivo phenotypes; whereas the lowa deposits coexist with neurofibrillary tangles and manifest with memory impairment classic of $A D$, the Dutch mutant translates in recurrent cerebral hemorrhage episodes in the absence of neurofibrillar pathology. Interestingly, genetically engineered mice carrying both the Dutch and lowa double mutation show early onset accumulation of fibrillar deposits in cerebral microvessels together with the presence of largely diffuse parenchymal lesions. Thus, the final pathology resulting from the existence of these mutants appears to be a consequence of complex mechanisms that go beyond the mere presence of $\beta$-sheet structures and peptide multimerization.

Mounting evidence suggests that plaque burden correlates poorly with the degree of dementia and that soluble intermediate assemblies including protofibrils/oligomers rather than the insoluble amyloid fibrils are more relevant species for neuronal toxicity and dysfunction, in 
contrast with earlier studies attributing these effects to the presence of fibrillar components. ${ }^{74-79}$ This concept is strongly supported by the lowa form of FAD-in which parenchymal neuritic plaques are almost nonexistentand reinforced by two non-A $\beta$ amyloidoses, familial British and Danish dementias, ${ }^{23,80}$ also presenting with widespread preamyloid lesions and severe CAA. Despite structural differences among $A B r i, A D a n$, and $A \beta$, the extensive neurofibrillar degeneration with neurofibrillary tangles identical to those found in $A D$ cases in the virtual absence of compact plaques and the same clinical outcome (AD-like dementia) argue against the sole significance of compact plaques in the mechanism of neurodegeneration. ${ }^{24}$ These diseases clearly illustrate that the development of dementia is neither exclusive for $A \beta$ nor dependent on the presence of compact plaques. We propose that these disorders constitute excellent models to study early steps of peptide oligomerization/fibrillization as well as the role of preamyloid and vascular involvement in the complex scenario of amyloid-related neurodegeneration

\section{References}

1. Ghiso J, Frangione B: Amyloidosis and Alzheimer's disease. Adv Drug Delivery Rev 2002, 54:1539-1551

2. Zhang-Nunes SX, Maat-Schieman M, van Duinen $S$, Roos R, Frosch MP, Greenberg SM: The cerebral $\beta$-amyloid angiopathies: hereditary and sporadic. Brain Pathol 2006, 16:30-39

3. Revesz T, Holton JL, Lashley T, Plant G, Frangione B, Rostagno A, Ghiso J: Genetics and molecular pathogenesis of sporadic and hereditary cerebral amyloid angiopathies. Acta Neuropathol 2009, 118:115-130

4. Di Fede G, Catania M, Morbin M, Rossi G, Suardi S, Mazzoleni G, Merlin M, Giovagnoli AR, Prioni S, Erbetta A, Falcone C, Gobbi M, Colombo L, Bastone A, Beeg M, Manzoni C, Francescucci B, Spagnoli A, Cantù L, Del Favero E, Levy E, Salmona M, Tagliavini F: A recessive mutation in the APP gene with dominant-negative effect on amyloidogenesis. Science 2009, 323:1473-1477

5. Janssen JC, Beck JA, Campbell TA, Dickinson A, Fox NC, Harvey RJ, Houlden H, Rossor MN, Collinge J: Early onset familial Alzheimer's disease: mutation frequency in 31 families. Neurology 2003, 60:235-239

6. Wakutani Y, Watanabe K, Adachi Y, Wada-Isoe K, Urakami K, Ninomiya H, Saido TC, Hashimoto T, Iwatsubo T, Nakashima K: Novel amyloid precursor protein gene missense mutation (D678N) in probable familial Alzheimer's disease. J Neurol Neurosurg Psychiatry 2004, 75:1039-1042

7. Hendriks L, van Duijn CM, Cras P, Cruts M, Van Hul W, van Harskamp F, Warren A, McInnis MG, Antonarakis SE, Martin JJ, Hofman A, Van Broeckhoven C: Presenile dementia and cerebral haemorrhage linked to a mutation at codon 692 of the $\beta$-amyloid precursor protein gene. Nat Genet 1992, 1:218-221

8. Levy E, Carman MD, Fernandez Madrid IJ, Power MD, Lieberburg I, van Duinen SG, Frangione B: Mutation of the Alzheimer's disease amyloid gene in hereditary cerebral hemorrhage, Dutch type. Science 1990, 248:1124-1126

9. Miravalle L, Tokuda T, Chiarle R, Giaccone G, Bugiani O, Tagliavini F, Frangione B, Ghiso J: Substitution at codon 22 of Alzheimer's A $\beta$ peptide induce diverse conformational changes and apoptotic effects in human cerebral endothelial cells. J Biol Chem 2000, 275:27110-27116

10. Nilsberth C, Westlind-Danielsson A, Eckman CB, Condron MM, Axelman K, Forsell C, Stenh C, Luthman J, Teplow DB, Younkin SG, Naslund J, Lannfelt L: The 'Arctic' APP mutation (E693G) causes Alzheimer's disease by enhanced Abeta protofibril formation. Nat Neurosci 2001, 4:887-893

11. Kamino K, Orr HT, Payami H, Wijsman EM, Alonso ME, Pulst SM, Anderson L, O'dahl S, Nemens E, White JA, Sadovnick AD, Ball MJ, Kaye JA, Warren A, McInnis MG, Antonarakis SE, Korenberg JR, Sharma V, Kukull WA, Larson EB, Heston LL, Martin GM, Bird TD,
Schellenberg GD: Linkage and mutational analysis of familial Alzheimer disease kindreds for the APP gene region. Am J Hum Genet 1992, 51:998-1014

12. Tomiyama $T$, Nagata $T$, Shimada $H$, Teraoka $R$, Fukushima $A$, Kanemitsu H, Takuma H, Kuwano R, Imagawa M, Ataka S, Wada Y Yoshioka E, Nishizaki T, Watanabe Y, Mori H: A new amyloid $\beta$ variant favoring oligomerization in Alzheimer's-type dementia. Ann Neurol 2008, 63:377-387

13. Grabowski TJ, Cho HS, Vonsattel JPG, Rebeck GW, Greenberg SM: A novel APP mutation in an lowa family with dementia and severe cerebral amyloid angiopathy. Ann Neurol 2001, 49:697-705

14. Obici L, Demarchi A, de Rosa G, Bellotti V, Marciano S, Donadei S, Arbustini E, Palladini G, Diegoli M, Genovese E, Ferrari G, Coverlizza S, Merlini G: A novel A $\beta P P$ mutation exclusively associated with cerebral amyloid angiopathy. Ann Neurol 2005, 58:639-644

15. Rossi G, Giaccone G, Maletta R, Morbin M, Capobianco R, Mangieri M, Giovagnoli AR, Bizzi A, Tomaino C, Perri M, Di Natale M, Tagliavini F, Bugiani O, Bruni AC: A family with Alzheimer disease and strokes associated with A713T mutation of the APP gene. Neurology 2004, 63:910-912

16. Armstrong J, Boada M, Rey MJ, Vidal N, Ferrer I: Familial Alzheimer disease associated with A713T mutation in APP. NeuroReport 2004, 370:241-243

17. Bornebroek M, Haan J, Roos N: Hereditary cerebral hemorrhage with amyloidosis-Dutch type (HCHWA-D): a review of the variety in phenotypic expression. Amyloid 1999, 6:215-224

18. Herzig MC, Winkler DT, Burgermeister P, Pfeifer M, Kohler E, Schmidt SD, Danner S, Abramowski D, Stürchler-Pierrat C, Bürki K, van Duinen SG, Maat-Schieman MLC, Staufenbiel M, Mathews PM, Jucker $M: A \beta$ is targeted to the vasculature in a mouse model of hereditary cerebral hemorrhage with amyloidosis. Nat Neurosci 2004, 7:954-960

19. Maat-Schieman M, Roos R, van Duinen S: Hereditary cerebral hemorrhage with amyloidosis-Dutch type. Neuropathology 2005, 25:288-297

20. Nishitsuji K, Tomiyama T, Ishibashi K, Ito K, Teraoka R, Lambert MP, Klein WL, Mori H: The E693 $\Delta$ mutation in amyloid precursor protein increases intracellular accumulation of amyloid $\beta$ oligomers and causes endoplasmic reticulum stress-induced apoptosis in cultured cells. Am J Pathol 2009, 174:957-969

21. Takuma $\mathrm{H}$, Teraoka R, Mori H, Tomiyama T: Amyloid $\beta$ E22 $\Delta$ variant induces synapse alteration in mouse hippocampal slices. NeuroReport 2007, 19:615-619

22. Greenberg SM, Shin Y, Grabowski TJ, Cooper GE, Rebeck GW, Iglesias S, Chapon F, Tournier-Lasserve E, Baron JC: Hemorrhagic stroke associated with the lowa amyloid precursor protein mutation. Neurology 2003, 60:1020-1022

23. Vidal R, Ghiso J, Revesz T, Rostagno A, Kim E, Holton J, Bek T, Bojsen-Moller M, Braendgaard H, Plant G, Frangione B: A decamer duplication in the $3^{\prime}$ region of the $\mathrm{BRI}$ gene originates a new amyloid peptide that is associated with dementia in a Danish kindred. Proc Natl Acad Sci USA 2000, 97:4920-4925

24. Rostagno A, Ghiso J: Preamyloid lesions and cerebrovascular deposits in the mechanism of dementia: lessons from non- $\beta$-amyloid cerebral amyloidosis. Neurodegener Dis 2008, 5:173-175

25. Castano EM, Prelli F, Soto C, Beavis R, Matsubara E, Shoji M, Frangione B: The length of amyloid- $\beta$ in hereditary cerebral hemorrhage with amyloidosis, Dutch type: implications for the role of amyloid- $\beta$ 1-42 in Alzheimer's disease. J Biol Chem 1996, 271:32185-32191

26. Prelli F, Levy E, van Duinen SG, Bots GT, Luyendijk W, Frangione B: Expression of a normal and variant Alzheimer's $\beta$-protein gene in amyloid of hereditary cerebral hemorrhage, Dutch type: dNA and protein diagnostic assays. Biochem Biophys Res Comm 1990, 170:301-307

27. Fossati S, Cam J, Meyerson J, Mezhericher E, Romero IA, Couraud P-O, Weksler B, Ghiso J, Rostagno A: Differential activation of mitochondrial apoptotic pathways by vasculotropic amyloid- $\beta$ variants in cells composing the cerebral vessel walls. FASEB J 2010, 24:229-241

28. Tomidokoro Y, Lashley T, Rostagno A, Neubert TA, Bojsen-Moller M, Braendgaard H, Plant G, Holton J, Frangione B, Revesz T, Ghiso J: Familial Danish dementia: co-existence of $A D a n$ and $A \beta$ amyloid subunits in the absence of compact plaques. J Biol Chem 2005, 280:36883-36894

29. Rostagno A, Ghiso J: Isolation and biochemical characterization of amyloid plaques and paired helical filaments. Curr Protoc Cell Biol 2009, Chapter 3:3.33.31-33.33.33 
30. Wang R, Sweeney D, Gandy SE, Sisodia SS: The profile of soluble amyloid $\beta$ protein in cultured cell media: detection and quantification of amyloid $\beta$ protein and variants by immunoprecipitation-mass spectrometry. J Biol Chem 1996, 271:31894-31902

31. Ghiso J, Holton J, Miravalle L, Calero M, Lashley T, Vidal R, Houlden H, Wood N, Neubert TA, Rostagno A, Plant G, Revesz T, Frangione B Systemic amyloid deposits in familial British dementia. J Biol Chem 2001, 276:43909-43914

32. Woods AS, Buchsbaum JC, Worrall TS, Berg JM, Cotter RJ: Matrixassisted laser desorption/lonization of noncovalently bound compounds. Anal Chem 1995, 67:4462-4465

33. Ida N, Hartmann T, Pantel J, Schroder J, Zerfass R, Forstl H, Sandbrink $\mathrm{R}$, Masters CL, Beyreuther K: Analysis of heterogeneous A4 peptides in human cerebrospinal fluid and blood by a newly developed sensitive Western blot assay. J Biol Chem 1996, 271:22908-22914

34. Tomidokoro Y, Rostagno A, Greenberg SM, Frangione B, Rebeck GW, Ghiso J: Biochemical analysis of $A \beta$ amyloid deposits in the lowa variant of Alzheimer's disease. Neurobiol Aging 2004, 25:38

35. Johnson BA, Aswad DW: Optimal conditions for the use of protein L-isoaspartyl methyltransferase in assessing the isoaspartate content of peptides and proteins. Anal Biochem 1991, 192:384-391

36. Stine WBJ, Dahlgren KN, Krafft GA, LaDu MJ: In vitro characterization of conditions for amyloid- $\beta$ peptide oligomerization and fibrillogenesis. J Biol Chem 2003, 278:11612-11622

37. Walsh DM, Hartley DM, Kusumoto Y, Fezoui Y, Condron MM, Lomakin A Benedek GB, Selkoe D, Teplow D: Amyloid $\beta$-protein fibrillogenesis: structure and biological activity of protofribrillar intermediates. J Biol Chem 1999, 274:25945-25952

38. Solito R, Corti F, Fossati S, Mezhericher E, Donnini S, Ghiso J, Giachetti A, Rostagno A, Ziche M: Dutch and Arctic mutant peptides of $\beta$ amyloid(1-40) differentially affect the FGF-2 pathway in brain endothelium. Exp Cell Res 2009, 315:385-395

39. Viana RJ, Nunes AF, Castro RE, Ramalho RM, Meyerson J, Fossati S, Ghiso J, Rostagno A, Rodrigues CM: Tauroursodeoxycholic acid prevents E22Q Alzheimer's $A \beta$ toxicity in human cerebral endothelial cells. Cell Mol Life Sci 2009, 66:1094-1104

40. Roher AE, Lowenson JD, Clarke S, Wolkow C, Wang R, Cotter RJ, Reardon IM, Zurcher-Neely HA, Heinrikson RL, Ball MJ, Greenberg $\mathrm{BD}$ : Structural alterations in the peptide backbone of $\beta$-amyloid core protein may account for its deposition and stability in Alzheimer's disease. J Biol Chem 1993, 268:3072-3083

41. Roher AE, Lowenson JD, Clarke S, Woods AS, Cotter RJ, Gowing E, Ball MJ: $\beta$-Amyloid-(1-42) is a major component of cerebrovascular amyloid deposits: implications for the pathology of Alzheimer disease. Proc Natl Acad Sci USA 1993, 90:10836-10840

42. Shin $Y$, Cho HS, Fukumoto H, Shimizu T, Shirasawa T, Greenberg SM, Rebeck GW: A $\beta$ species, including IsoAsp23 A $\beta$, in lowa-type familial cerebral amyloid angiopathy. Acta Neuropathol 2003, 105:252-258

43. Tomidokoro $\mathrm{Y}$, Lashley $\mathrm{T}$, Revesz $\mathrm{T}$, Greenberg BD, Frangione B, Rostagno A, Ghiso J: Matrix metalloproteases and $A \beta$ clearance. Alzheimer's Dementia 2006, 2:S536-S537

44. Holton J, Lashley T, Ghiso J, Braendgaard H, Vidal R, Guerin C, Gibb G, Hanger DP, Rostagno A, Anderton B, Strand C, Ayling H, Plant G Frangione B, Bojsen-Moller M, Revesz T: Familial Danish Dementia: a novel form of cerebral amyloidosis associated with deposition of both amyloid-Dan and amyloid- $\beta$. J Neuropathol Exp Neurol 2002, 61:254-267

45. Kuo YM, Emmerling MR, Woods AS, Cotter RJ, Roher AE: Isolation, chemical characterization, and quantitation of $\mathrm{A} \beta$ 3-pyroglutamyl peptide from neuritic plaques and vascular amyloid deposits. Biochem Biophys Res Comm 1997, 237:188-191

46. Iwatsubo T, Saido T, Mann DM, Lee V, Trojanowski JQ: Full-length amyloid- $\beta 1-42(43)$ and amino-terminally modified and truncated amyloid- $\beta$ 1-42(43) deposit in diffuse plaques. Am J Pathol 1996 149:1823-1830

47. Portelius E, Westman-Brinkmalm A, Zetterberg H, Blennow K: Determination of $\beta$-amyloid peptide signatures in cerebrospinal fluid using immunoprecipitation-mass spectrometry. J Proteome Res 2006 5:1010-1016

48. Portelius E, Zetterberg $\mathrm{H}$, Andreasson $\mathrm{U}$, Brinkmalm G, Andreasen N, Wallin A, Westman-Brinkmalm A, Blennow K: An Alzheimer's diseasespecific $\beta$-amyloid fragment signature in cerebrospinal fluid. Neurosci Lett 2006, 409:215-219

49. Morelli L, Llovera R, Ibemdahl S, Castaño EM: The degradation of amyloid beta as a therapeutic strategy in Alzheimer's disease and cerebrovascular amyloidosis. Neurochem Res 2002, 27:1387-1399

50. Wang Y-J, Zhou H-D, Xin-Fu Zhou X-F: Clearance of amyloid- $\beta$ in Alzheimer's disease: progress, problems and perspectives. Drug Disc Today 2006, 11:931-938

51. Morelli L, Llovera R, Gonzalez SA, Affranchino JL, Prelli F, Frangione $B$, Ghiso J, Castaño EM: Differential degradation of AB genetic variants associated with hereditary dementia or stroke by insulin-degraded enzyme (IDE). J Biol Chem 2003, 278:23221-23226

52. Howell S, Nalbantoglu J, Crine P: Neutral endopeptidase can hydrolyze $\beta$-amyloid(1-40) but shows no effect in $\beta$-amyloid procursor protein metabolism. Peptides 1995, 16:647-652

53. Junaid MA, Wu G, Pullarkat RK: Purification and characterization of bovine brain lysosomal pepstatin-insensitive proteinase, the gene product deficient in the human late-infantile neuronal ceroid lipofuscinosis. J Neurochem 2000, 74:287-294

54. Backstrom JR, Lim GP, Cullen MJ, Tokes ZA: Matrix metalloproteinase-9 (MMP-9) is synthesized in neurons of the human hippocampus and is capable of degrading the amyloid-beta peptide (1-40). J Neurosci 1996, 16:7910-7919

55. Hamazaki H: Cathepsin D is involved in the clearance of Alzheimer's $\beta$-amyloid protein. FEBS Lett 1996, 396:139-142

56. Beher D, Wrigley JD, Owens AP, Shearman MS: Generation of Cterminally truncated amyloid- $\beta$ peptides is dependent on $\gamma$-secretase activity. J Neurochem 2002, 82:563-575

57. Fluhrer R, Multhaup G, Schlicksupp A, Okochi M, Takeda M, Lammich S, Willem M, Westmeyer G, Bode W, Walter J, Haass C: identification of a $\beta$-secretase activity, which truncates amyloid- $\beta$ peptide after its presenilin-dependent generation. J Biol Chem 2003, 278:5531-5538

58. Murphy MP, Hickman IJ, Eckman C, Uljon SN, Wang R, Golde TE: $\gamma$-Secretase, evidence for multiple proteolytic activities and influence of membrane positioning of substrate on generation of amyloid $\beta$ peptides of varying length. J Biol Chem 1999, 274:11914-11923

59. Gabizon R, Telling G, Meiner Z, Halimi M, Kahana I, Prusiner SB: Insoluble wild-type and protease-resistant mutant prion protein in brains of patients with inherited prion disease. Nat Med 1996, 2:59-64

60. Ando Y, Ando E, Ohlsson P.-I., Olofsson A, Sandgren O, Suhr O, Terazaki H, Obayashi K, Lundgren E, Ando M, Negi A: Analysis of transthyretin amyloid fibrils from vitreous samples in familial amyloidotic polyneuropathy (Val30Met). Amyloid 1999, 6:119-123

61. Thylén C, Wahlqvist J, Haettner E, Sandgren O, Holmgren G, Lundgren E: Modification of transthyretin in amyloid fibrils: analysis of amyloid from homozygous and heterozygous individuals with the Met30 mutation. EMBO J 1993, 12:743-748

62. Dwulet FE, Benson MD: Characterization of a transthyretin (prealbu$\mathrm{min}$ ) variant associated with familial amyloidotic polyneuropathy type II (Indiana/Swiss). J Clin Invest 1986, 78:880-886

63. Yazaki M, Tokuda T, Nakamura A, Higashikata T, Koyama J, Higuchi K, Harihara Y, Baba S, Kametani F, Ikeda S: -I.: Cardiac amyloid in patients with familial amyloid polyneuropathy consists of abundant wild-type transthyretin. Biochem Biophys Res Commun 2000, 274:702-706

64. Yazaki M, Liepnieks JJ, Kincaid JC, Benson MD: Contribution of wild-type transthyretin to hereditary peripheral nerve amyloid. Muscle Nerve 2003, 28:438-442

65. Frangione B, Wisniewski T, Tagliavini F, Bugiani O, Ghiso J: Alzheimer's disease and Dutch variant: opposing faces of a single coin; Alzheimer's disease: Advances in clinical and basic research. Edited by B Corain, $\mathrm{K}$ Iqbal, B Nicolini, B Winblad, HM Wisniewski, and P Zatta. Chichester, U.K., John Wiley and Sons 1993, pp 387-396

66. Wisniewski T, Golabek AA, Kida E, Wisniewski KE, Frangione B: Conformational mimicry in Alzheimer's disease: role of apolipoproteins in amyloidogenesis. Am J Pathol 1995, 147:238-244

67. Shimizu T, Fukuda H, Murayama S, Izumiyama N, Shirasawa T: Isoaspartate formation at position 23 of amyloid $\beta$ peptide enhanced fibril formation and deposited onto senile plaques and vascular amyloids in Alzheimer's disease. J Neurosci Res 2002, 70:451-461

68. Geiger T, Clarke S: Deamidation, isomerization, and racemization at asparaginyl and aspartyl residues in peptides: succinimide-linked reactions that contribute to protein degradation. J Biol Chem 1987, 262:785-794

69. Robinson NE, Robinson AB: Deamidation of human proteins. Proc Natl Acad Sci USA 2001, 98:12409-12413 
70. Lindner $\mathrm{H}$, Helliger W: Age-dependent deamidation of asparagine residues in proteins. Exp Gerontol 2001, 36:1551-1563

71. Kuo YM, Webster S, Emmerling MR, De Lima N, Roher AE: Irreversible dimerization/tetramerization and post-translational modifications inhibit proteolytic degradation of $A \beta$ peptides of Alzheimer's disease. Biochim Biophys Acta 1998, 1406:291-298

72. van Nostrand WE, Melchor JP, Cho HS, Greenberg SM, Rebeck GW: Pathogenic effects of D23N lowa mutant amyloid $\beta$-protein. J Biol Chem 2001, 276:32860-32866

73. Davis JB, Cribbs DH, Cotman CW, van Nostrand WE: Pathogenic amyloid $\beta$-protein induces apoptosis in cultured human cerebrovascular smooth muscle. Amyloid 1999, 6:157-164

74. Lorenzo A, Yankner BA: $\beta$-amyloid neurotoxicity requires fibril formation and is inhibited by Congo red. Proc Natl Acad Sci USA 1994, 91:12243-12247
75. Klein WL, Krafft GA, Finch $C$ : Targeting small $A \beta$ oligomers: the solution to an Alzheimer's disease conundrum? Trends Neurosci 2001, 24:219-224

76. Lansbury PT: Amyloid diseases: abnormal protein aggregation in neurodegeneration. Proc Natl Acad Sci USA 1999, 96:3342-3344

77. Small DH: The amyloid cascade hypothesis debate: emerging consensus on the role of $A \beta$ and amyloid in Alzheimer's disease. Amyloid: intl J Exp Clin Invest 1998, 5:301-304

78. Haass $\mathrm{C}$, Steiner H: Protofibrils, the unifying toxic molecule of neurodegenerative disorders? Nat Neurosci 2001, 4:859-860

79. Walsh DM, Selkoe DJ: A $\beta$ oligomers: a decade of discovery. J Neurochem 2007, 101:1172-1184

80. Vidal R, Frangione B, Rostagno A, Mead S, Revesz T, Plant G, Ghiso $\mathrm{J}$ : A stop-codon mutation in the BRI gene associated with familial $\mathrm{Br}$ dementia. Nature 1999, 399:776-781 